\title{
Penerapan Model Pembelajaran Multilierasi Informasi Untuk Meningkatkan Pemahaman Konsep Jual Beli
}

\author{
Budi Febriyanto ${ }^{1}$, Ari Yanto ${ }^{2}$ \\ 1,2Universitas Majalengka, Indonesia
}

Corresponding Author: Budi Febriyanto, E-mail: budifebriyanto88@gmail.com

\begin{tabular}{|c|c|}
\hline & ABSTRACT \\
\hline $\begin{array}{c}\text { ARTICLE INFO } \\
\text { Article history: } \\
\text { Received } \\
6 \text { April } 2019 \\
\text { Revised } \\
7 \text { May } 2019 \\
\text { Accepted } \\
\text { 26 May } 2019\end{array}$ & $\begin{array}{l}\text { This article aimed to improve the understanding of the concept of } \\
\text { purchase and sale in class III Elementary School of Mekarjaya III } \\
\text { through the application of information multiliterasi learning models. } \\
\text { This research was classroom action research. This research was } \\
\text { conducted in three cycles. The results showed that the percentage of } \\
\text { classical completeness in the first cycle has average } 63.2 \text { with the } \\
\text { percentage of classical completeness which was } 48.5 \% \text {. In the second } \\
\text { cycle the average score of students were } 70 \text { with the percentage of } \\
\text { classical completeness } 63.6 \% \text {. In the third cycle the average value of } \\
\text { students were } 81.2 \text { with the percentage of classical completeness } \\
87.9 \% \text {. Then it can be concluded that the application of the } \\
\text { multiliteration learning model of information on social studies subjects } \\
\text { has success to increase the understanding of the concept purchase and } \\
\text { sale in class III Elementary School of Mekarjaya III District Majalengka. } \\
\text { Key words: Multiliteration Information Model, Understanding of Purchase } \\
\text { and Sale }\end{array}$ \\
\hline $\begin{array}{l}\text { DOI } \\
\text { Journal Homepage } \\
\text { This is an open acce }\end{array}$ & 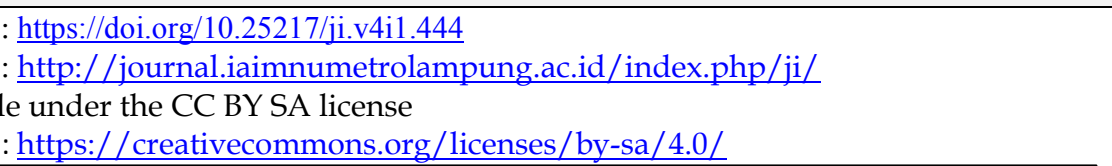 \\
\hline
\end{tabular}

\section{PENDAHULUAN}

Kemajuan zaman menghadapkan manusia pada sejumlah tantangan yang harus dihadapi dengan kemampuan pemahaman yang baik. Kaitannya dengan hal tersebut didukung oleh pernyataan Marocco bahwa pada abad ke21 terdapat tiga kompetensi yang harus dimiliki oleh manusia yakni kompetensi pemahaman yang tinggi, kompetensi berpikir kritis, kompetensi berkolaborasi dan berkomunikasi (Abidin, 2016). Berdasarkan pernyataan di atas, pemahaman menjadi salah satu kompetensi yang harus dimiliki oleh manusia sebagai kemampuan yang sekaligus menjadi kekuatan untuk menghadapi kemajuan. Rendahnya tingkat pemahaman akan mempersulit individu karena tidak mampu menerima, menyerap, dan memahami serta mengerti apa yang dibacanya, dilihat, dialami, atau yang dirasakan. Hal 
tersebut berdampak ketika menghadapi permasalahan, seseorang kesulitan dalam menyelesaikan permasalahan tersebut. Terdapat sejumlah kemampuan yang dimiliki oleh peserta didik ketika telah memiliki pemahaman konsep. Seperti dijelaskan Adriana dan Setiawan bahwa pemahaman konsep adalah kemampuan mengungkapkan makna atau konsep yang meliputi kemampuan membedakan, menjelaskan, menguraikan lebih lanjut, dan mengubah konsep (Adriana \& Setiawan, 2015). Jadi dapat dipahami bahwa pemahaman konsep merupakan sejumlah kemampuan yang dimiliki oleh peserta didik ketika telah berhasil memahami makna suatu konsep atau makna dari apa yang telah dipelajarinya kemudian kemampuan tersebut selanjutnya dapat digunakan dalam kehidupan sehari-hari.

Berdasarkan studi pendahuluan penelitian diperoleh hasil bahwa sebanyak 20 siswa (71\%) belum memenuhi kriteria ketuntasan minimal (KKM) kelas IV SD Rawa Buaya 03 Pagi yaitu 67 sehingga menunjukkan rendahnya tingkat penguasaan siswa terhadap materi pelajaran matematika, khususnya pada materi besar sudut (Mariyana et al. 2018). Selain itu, penelitian lainnya yang dilakukan oleh Puspitasari dan Kamsiayati mengungkapkan bahwa berdasarkan hasil tes pratindakan yang telah dilaksanakan di kelas III SDN 01 Tengklik pemahaman konsep materi pengukuran masih sangat rendah yaitu hanya ada 10 siswa yang mendapat nilai di atas KKM (Puspitasari \& Kamsiyati, 2015). Selanjutnya, penelitian Siti Hawa dkk mengemukakan pemahaman konsep sifat benda cair masih rendah, karena nilai yang dicapai oleh siswa tidak mencapai standar nilai KKM yang telah ditetapkan sekolah yaitu untuk mata pelajaran sains sebesar 65 dan ketuntasan klasikal yaitu 70 (Hawa \& Ramadhan, 2013). Berdasarkan kajian dari beberapa literatur tersebut menunjukkan rendahnya pemahaman konsep materi besar sudut dan pengukuran pada mata pelajaran matematika serta materi sifat benda cair pada mata pelajaran IPA. Pada penelitian ini fokus kajian pada pemahaman konsep jual beli pada mata pelajaran IPS di kelas III SD.

Proses pembelajaran IPS mampu membina peserta didik dalam rangka meningkatkan kualitas sumber daya manusia. Peserta didik dipersiapkan untuk menjadi anggota masyarakat yang memiliki nilai-nilai positif karena IPS dikembangkan sesuai dengan keadaan lingkungan siswa, sesuai dengan kebutuhan siswa, siswa dibina sehingga memiliki pengetahuan, pemahaman, dan keterampilan. Namun pada kenyataannya proses pembelajaran IPS belum sesuai dengan harapan. Seperti yang dikemukakan oleh Sutarna (2018) bahwa banyak problem dalam proses kegiatan pembelajaran termasuk didalamnya pembelajaran IPS. Siswa belum banyak dilibatkan dalam proses kegiatan pembelajaran sehingga berdampak pada pemerolehan hasil belajar siswa. 
Hasil observasi yang dilakukan di kelas III SD Negeri Mekarjaya III Kecamatan Kertajati Kabupaten Majalengka pada mata pelajaran IPS menunjukkan proses pembelajaran yang dilakukan belum mampu meningkatkan pemahaman siswa. Hal tersebut didukung oleh data nilai hasil ulangan harian mata pelajaran IPS yang menunjukan masih banyak peserta didik yang belum mencapai Kriteria Ketuntasan Minimal (KKM) yaitu 67. Dari 33 siswa hanya $15(45,4 \%)$ siswa yang tuntas mendapatkan nilai di atas KKM. Maka dapat dikatakan pembelajaran IPS di SD Negeri Mekarjaya III belum mencapai kriteria ketuntasan sebesar $85 \%$. Oleh karena itu perlu dilakukan upaya dalam meningkatkan kualitas pembelajaran agar beroleh kemampuan pemahaman konsep yang diharapkan.

Model pembelajaran multiliterasi informasi menjadi hal yang penting dalam mencari alternatif solusi untuk meningkatkan kualitas pembelajaran IPS, agar diperoleh kemampuan pemahaman konsep yang diharapkan. Penelitian sebelumnya yang dilakukan oleh Dafit menunjukkan bahwa pembelajaran multiliterasi mampu meningkatkan kemampuan siswa dalamme mahami bacaan (Dafit, 2017a). Selanjutnya penelitian Pramida menunjukkan penggunaan model pembelajaran multiliterasi secara signifikan efektif terhadap pengembangan keterampilan literasi media peserta didik aspek critical understanding sebelum dan sesudah menerapkan model pembelajaran multiliterasi (Deuis et al. 2018). Kedua penelitian tersebut menunjukkan bahwa model pembelajaran multiliterasi memberikan dampak positif terhadap pembelajaran. Berbeda dengan penelitian di atas, penelitian ini menggunakan model pembelajaran multiliterasi informasi yang merupakan modifikasi model pembelajaran multiliterasi sebagai solusi untuk meningkatkan kualitas pembelajaran. Model multiliterasi informasi dalam praktiknya mampu membantu siswa untuk mencari tahu sehingga proses pembelajaran tidak lagi berfokus pada siswa sebagai penerima informasi tetapi siswa ditugaskan untuk menemukan sebanyak mungkin informasi dari berbagai sumber. Siswa akan menetapkan masalah, membuat pertanyaan pemandu, menemukan sumber informasi, mencatat informasi, menyeleksi informasi, mengolah informasi, menyimpulkan informasi, dan memproduksi karya sehingga peserta didik mampu beroleh pemahaman yang baik. Berdasarkan pemaparan tersebut, tujuan penelitian ini adalah untuk memperbaiki kualitas proses pembelajaran dengan menerapkan model multiliterasi informasi sehingga dapat meningkatkan pemahaman konsep jual beli pada pembelajaran IPS di Kelas III SD.

Model pembelajaran multiliterasi pada dasarnya memadukan berbagai keterampilan literasi dan sintaks model mengacu pada sintaks model literasi. 
Sintaks dasar model pembelajaran multiliterasi seperti yang telah dijelaskan oleh Abidin (2015) yaitu fase praaktivitas, fase aktivitas, dan fase pasca aktivitas. Jadi, sintaks tersebut adalah sintak dasar yang masih bisa dikembangkan kembali, berkaitan dengan model multiliterasi informasi pada fase pra aktivitas siswa melakukan persiapan belajar meliputi membuat pemandu, menemukan dan menetapkan berbagai sumber informasi, menetapkan topik atau masalah, pada fase aktivitas kegiatan yang dapat dilakukan siswa meliputi membaca, menulis, menyampaikan ide, menganalisis, menginferensi, menyimpulkan dan lain sebagainya, fase pasca aktivitas siswa meliputi menguji pemahaman, memproduksi berbagai produk hasil belajar. Penerapan model pembelajaran multiliterasi diharapkan mampu membantu mengatasi permasalahan proses pembelajaran yang dihadapi oleh guru agar siswa dapat meningkatkan kemampuan pemahaman konsep jual beli, maka peneliti melakukan penelitian tindakan kelas (PTK) dengan judul penerapan model pembelajaran multiliterasi informasi untuk meningkatkan pemahaman konsep jual beli.

\section{METODE PENELITIAN}

Penelitian ini dilakukan sesuai dengan metode yang digunakan yaitu dengan metode PTK. PTK yaitu upaya yang ditujukan untuk memperbaiki proses pembelajaran atau memecahkan masalah yang dihadapi dalam pembelajaran (Mulyasa, 2009). Berdasarkan pernyataan tersebut dapat disimpulkan bahwa PTK diarahkan dengan tujuan untuk memperbaiki, baik dari segi pemahaman yang berkaitan dengan kegiatan praktik pendidikan, proses pembelajaran, atau pun memecahkan permasalahan yang terdapat di dalam pembelajaran. Penelitian ini melibatkan guru dan subjek penelitian yang bersama-sama mengupayakan melakukan perbaikan. Maka dari itu perbaikan dilakukan oleh peneliti dengan melibatkan guru sebagai observer dan siswa sebagai subjek penelitian, perbaikan dilakukan sesuai kondisi yang berkesinambungan antara permasalahan yang ditemukan di SD Negeri Mekarjaya III yakni tingkat pemahaman konsep yang belum mencapai ketuntasan yaitu berkaitan dengan pemahaman siswa setelah mengikuti pembelajaran.

Penelitian terdiri dari tiga siklus dan setiap siklusnya terdiri dari tiga tindakan, tindakan satu dan dua melaksanakan proses pembelajaran dengan menggunakan model multiliterasi informasi dan tindakan tiga melakukan kegiatan tes evaluasi. Berikut adalah gambar alur penelitian tindakan kelas model Elliot (Rochiati, 2013). 
Gambar (Figure) 1.

Aktifitas Siswa Alur Siklus PTK Model Elliot

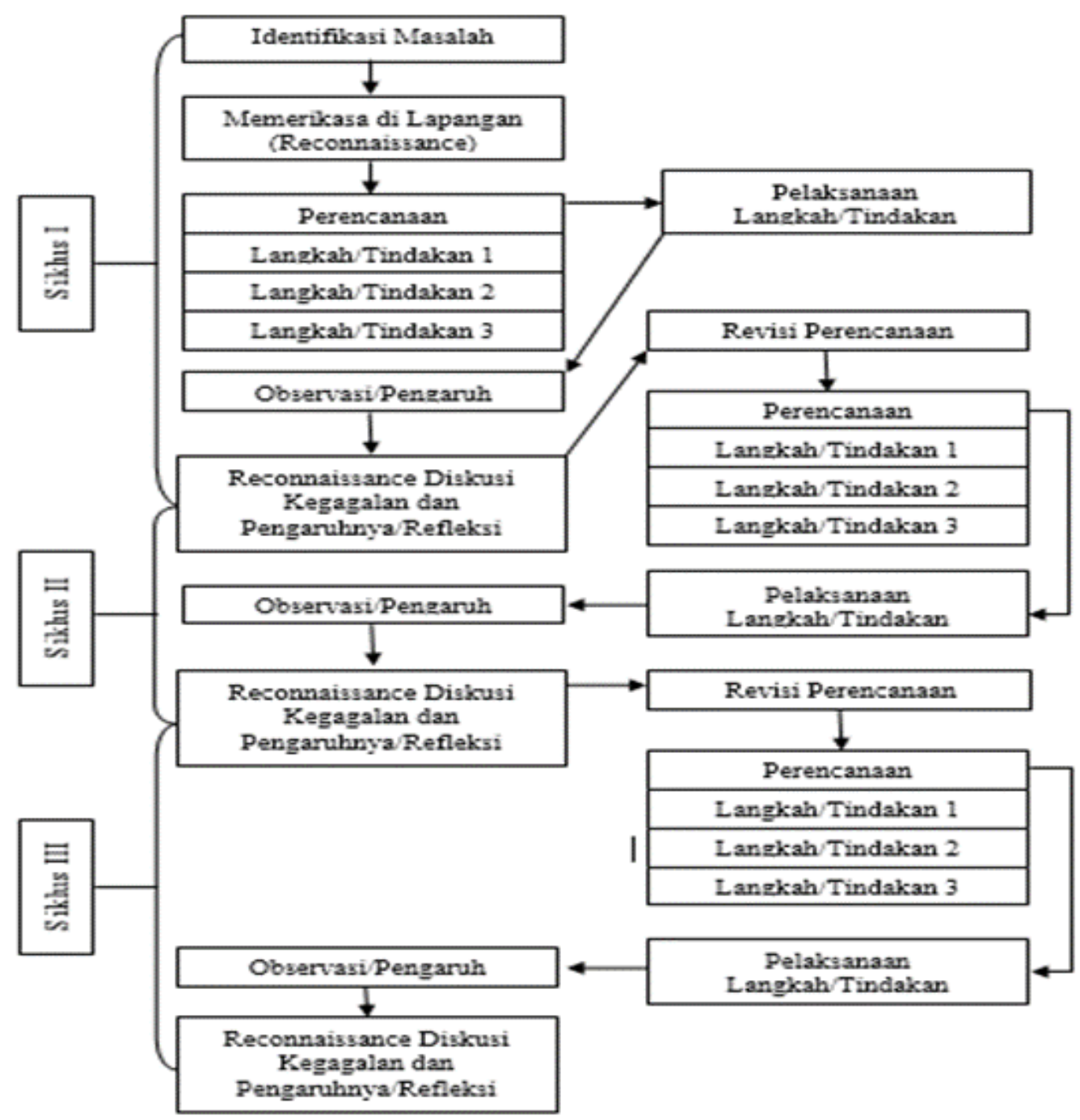

Tahap awal yang dilakukan oleh peneliti adalah menentukan masalah. Tahap identifikasi masalah yang dilakukan oleh peneliti diantaranya kegiatan mencari, menemukan, mengumpulkan, dan menelaah setiap permasalahan yang berhasil ditemukan dari lapangan pada kegiatan proses pembelajaran, permasalahan tersebut benar-benar nyata ada dan terjadi dilapangan. Reconnaissance merupakan tahap untuk menelaah dan mengamati kegiatan atau aktivitas siswa dalam pembelajaran. Aktivitas siswa dalam pembelajaran dikaji dan dipelajari oleh peneliti sehingga dari permaslahan yang telah teridentifikasi dapat diperoleh keputusan untuk melakukan perbaikan.

Tahap perencanaan yang disusun sedemikian rupa agar pelaksanaan penelitian berjalan dengan baik dan mencapai tujuan yang diharapkan. 
Pelaksanaan tindakan dilaksanakan berdasarkan perencanaan yang telah dibuat oleh peneliti. Pada tahap kegiatan observasi mengenai hasil dari pelaksanaan tindakan dalam satu siklus. Pelaksanaan tindakan penelitian diamati oleh observer selama proses tindakan berlangsung yakni proses pembelajaran IPS dengan menggunakan model multiliterasi informasi berdasarkan lembar observasi yang telah disiapkan oleh peneliti.

Refleksi dilakukan untuk menelaah dan merenungkan kembali data yang diperoleh dari hasil pengolahan data siklus pertama. Peneliti mempelajari kembali seluruh data yang berhasil di olah untuk melihat ketercapaian, kekurangan, dan kelebihan pada siklus pertama tersebut sehingga dapat menarik kesimpulan yang benar dari siklus pertama tersebut. Jadi, dengan refleksi dapat ditentukan perbaikan yang akan dilakukan pada siklus berikutnya.

Subjek penelitian yaitu siswa kelas III di SD Negeri Mekarjaya III yang berjumlah 33 siswa, terdiri dari 15 siswa perempuan dan 18 siswa laki-laki. Penelitian dilaksanakan di SD Negeri Mekarjaya III yang terletak di Dusun Cipakujaya RT.001 RW.007 Desa Mekarjaya Kecamatan Kertajati Kabupaten Majalengka Kode Pos 45457.

Instrumen yang digunakan dalam penelitian ini diantaranya lembar observasi, lembar wawancara, lembar catatan lapangan, dokumentasi, dan tes. Teknik analisis data yang digunakan dalam penelitian adalah analisis deskriptif kuantitatif untuk menganalisis hasil tes evaluasi siswa setiap siklus dan analisis deskriptif kualitatif untuk menganalisis hasil observasi, wawancara, dan catatan lapangan setiap siklus. Data hasil penelitian ini divalidasi dengan validasi bentuk triangulasi dan expert opinion.

\section{HASIL PENELITIAN DAN PEMBAHASAN}

Berdasarkan hasil evaluasi pemahaman konsep siklus pertama, dari seluruh siswa kelas III SD Negeri Mekarjaya III terdapat 16 (48,5\%) siswa yang tuntas, sedangkan $17(51,5 \%)$ siswa belum tuntas. Hal tersebut menunjukkan adanya peningkatan pada siklus pertama dari kondisi data awal yang tuntas sebanyak $15(45,5 \%)$ siswa dan 18 (54,5\%) belum tuntas. Maka penerapan model multiliterasi informasi masih kurang meningkatkan pemahaman konsep jual beli dengan jumlah 16 siswa yang telah mencapai KKM dengan nilai rata-rata 63,3 pada sub pokok kegiatan jual beli masih perlu peningkatan, akan tetapi sudah meningkat dari kondisi awal sebanyak 3\%.Persentase ketuntasan pemahaman konsep siklus pertama ditunjukkan pada gambar di bawah ini: 
Gambar (Figure) 2.

Grafik Persentase Ketuntasan Pemahaman Konsep Siklus Pertama

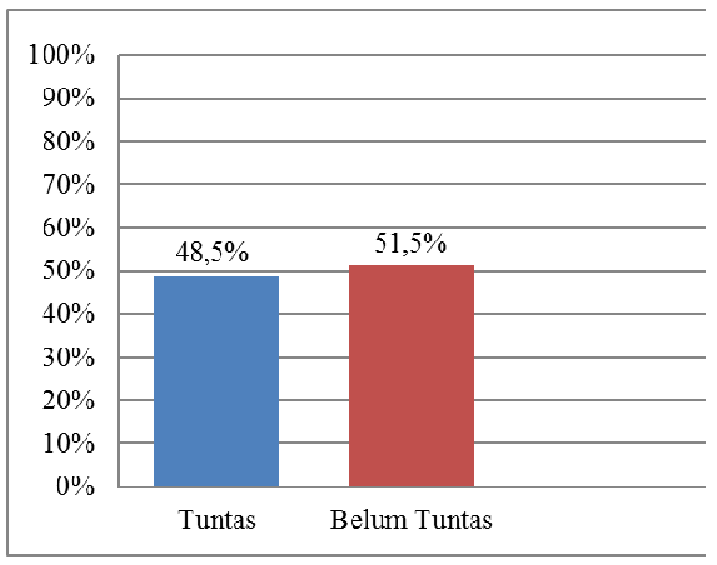

Berdasarkan hasil evaluasi siklus kedua dari seluruh siswa kelas III SD Negeri Mekarjaya III terdapat $21(63,6 \%)$ siswa yang tuntas, sedangkan 12 $(36,4 \%)$ siswa belum tuntas. Hal tersebut menunjukkan adanya peningkatan pada siklus dua dari siklus satu yakni yang tuntas sebanyak $16(48,5 \%)$ siswa dan $17(51,5 \%)$ belum tuntas. Maka penerapan model multiliterasi informasi pada siklus dua lebih baik dan dapat meningkatkan pemahaman konsep jual beli. Siswa yang telah mencapai KKM meningkat menjadi 21 siswa dengan nilai rata-rata 70 pada sub pokok tempat jual beli dan masih perlu peningkatan kembali, akan tetapi sudah lebih meningkat dari siklus pertama sebesar 15,1\%. Persentase ketuntasan pemahaman konsep siklus kedua ditunjukkan pada gambar di bawah ini.

\section{Gambar (Figure) 3.}

Grafik Persentase Ketuntasan Pemahaman Konsep Siklus Kedua

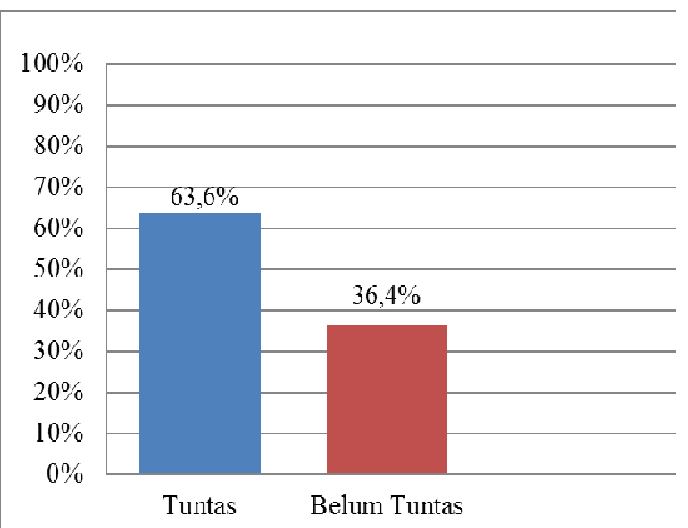

Berdasarkan hasil evaluası s1klus ketıga darı seluruh siswa kelas III SD Negeri Mekarjaya III terdapat 29 (87,9\%) siswa yang tuntas, sedangkan 4 $(12,1 \%)$ siswa belum tuntas. Hal tersebut menunjukkan adanya peningkatan 
pada siklus tiga dari siklus dua sebesar $24,3 \%$ yakni dengan jumlah siswa yang tuntas sebanyak $21(63,6 \%)$ siswa dan $12(36,4 \%)$ belum tuntas. Penerapan model multiliterasi informasi lebih baik lagi pada siklus tiga dan dapat meningkatkan pemahaman siswa lebih baik lagi pada siklus tiga. Siswa yang telah mencapai KKM mata pelajaran IPS SD Negeri Mekarjaya III yaitu 67 telah meningkat menjadi 29 siswa dengan nilai rata-rata 81,2 pada sub pokok proses jual beli. Hal tersebut telah menunjukan bahwa hasil evaluasi pemahaman konsep siswa siklus tiga telah mencapai ketuntasan klasikal lebih dari $85 \%$.

\section{Gambar (Figure) 4.}

Grafik Persentase Ketuntasan Pemahaman Konsep Siklus Ketiga

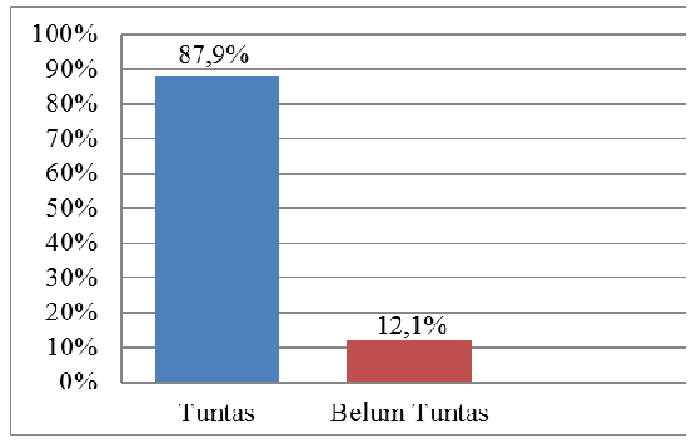

Secara keseluruhan pelaksanaan tindakan proses pembelajaran melalui penerapan model pembelajaran multiliterasi informasi di kelas III SD Negeri Mekarjaya III pada mata pelajaran IPS dalam meningkatkan pemahaman konsep siswa menunjukan adanya peningkatan pemahaman konsep yang dapat dilihat dari hasil evaluasi seperti berikut:

Gambar (Figure) 5.

Peningkatan Pemahaman Konsep

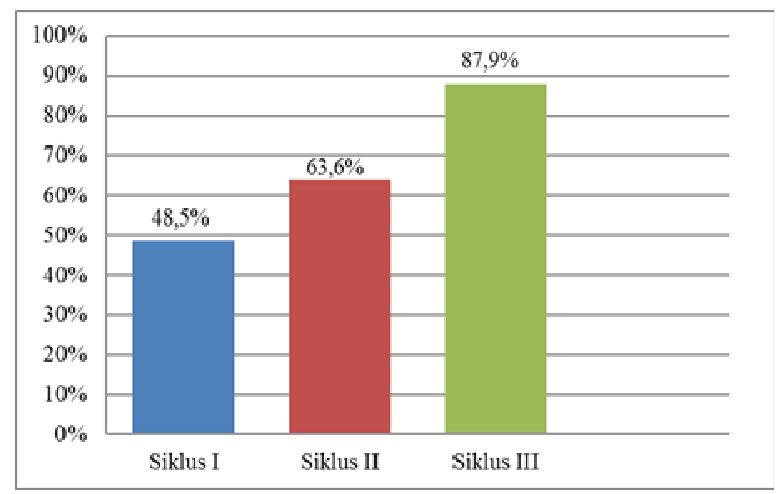

Berdasarkan gambar di atas terlihat bahwa hasil pengolahan data ketuntasan siswa dalam pemahaman konsep pada setiap siklus menunjukan 
adanya peningkatan. Hasil evaluasi siklus pertama dengan persentase ketuntasan klasikal adalah 48,5\% yang artinya belum mencapai ketuntasan klasikal yang telah ditetapkan. Hasil evaluasi siklus kedua dengan persentase ketuntasan klasikal yaitu 63,6\% artinya terdapat peningkatan dibandingkan dengan siklus pertama. Hasil evaluasi siklus ketiga pemahaman konsep siswa lebih meningkat lagi dan mencapai ketuntasan klasikal dengan persentase $87,9 \%$. Hasil evaluasi pemahaman konsep siswa kelas III SD Negeri Mekarjaya III terdapat peningkatan dari siklus pertama pada siklus dua sebesar $15,1 \%$ dan peningkatan dari siklus dua ke siklus tiga sebesar $24,3 \%$. Jadi total peningkatan dari siklus pertama ke siklus tiga sebesar 39,4\%.

Hasil observasi proses pembelajaran melalui lembar observasi guru dan siswa, catatan lapangan, lembar wawancara, dan dokumentasi menggambarkan proses pembelajaran yang telah dilaksanakan selama tiga siklus. Pelaksanaan proses pembelajaran IPS dengan menerapkan model pembelajaran multiliterasi informasi pada siklus pertama masih kurang baik. Antusias siswa masih kurang dan belum terbiasa belajar dengan cara mencari sendiri informasi yang akan dipelajarinya, dan melakukan banyak aktivitas pembelajaran. Pelaksanaan tindakan dengan menerapkan model pembelajaran multiliterasi informasi pada siklus kedua cukup mengalami perubahan dibandingkan hasil pada siklus pertama. Pelaksanaan tindakan pada siklus dua tersebut masih terdapat beberapa kesulitan tetapi ada juga peningkatan yang cukup baik. Pelaksanaan tindakan pada siklus tiga berdasarkan hasil observasi lebih baik dari sebelumnya dan lebih menunjukan peningkatan. Semua kegiatan terlaksana dengan baik dan berdasarkan perbaikan-perbaikan yang dilakukan memberikan perubahan lebih baik lagi. Penelitian yang dilakukan oleh Dafit mengemukakan bahwa dalam model multiliterasi, selama proses pembelajaran siswa diminta aktif mengeluarkan pendapat untuk mengoptimalkan kemampuan berbicara siswa, serta siswa dibimbing untuk dapat mendayagunakan media dan sumber belajar yang ada (Dafit, 2017b). Dengan demikian model pembelajaran multiliterasi membawa aktivitas pembelajaran ke arah yang lebih baik melalui peningkatan aktivitas siswa dan guru selama pembelajaran.

Peningkatan kualitas pembelajaran baik dalam proses pembelajaran dan pemahaman konsep pada tiap siklus tentunya karena beberapa faktor. Pertama, pemberian motivasi dalam meningkatkan aktivitas belajar. Pemberian motivasi dilakukan berdasarkan hasil refleksi untuk mengatasi rendahnya antusiame belajar siswa. Motivasi yang diberikan melalui tayangan video mengenai peristiwa jual beli serta nyanyian dan yel-yel membuat peserta didik antusias melakukan tanya jawab. Hal tersebut sejalan dengan penelitian Muhammad 
yang menyatakan bahwa motivasi belajar sebagai salah satu dari faktor-faktor psikologis turut memberikan kontribusi terhadap upaya pencapaian hasil belajar (Muhammad, 2016) Kedua, pemanfaatan teknologi dalam mencari sumber informasi menjadikan pembelajaran menjadi lebih dinamis. Dalam pembelajaran multiliterasi informasi yang diterapkan, peserta didik mencari informasi mengenai materi yang dipelajari salah satunya melalui penggunaan laptop pada tiap kelompok. Hardiyana (2016) mengemukakan penggunaan teknologi informasi dan komunikasi adalah bagian dari media pembelajaran yang dapat dimanfaatkan dalam aplikasi pembelajaran. Hal ini dapat mempermudah guru dalam mengelola dan menyampaikan pesan kepada peserta didik. Ketiga, kerjasama antara guru, siswa, dan kelompok siswa membuat pembelajaran menjadi lebih partsipatif. Peran guru dalam pembelajaran multiliterasi informasi yaitu salah satunya mengelola kelas menjadi sangat penting sehingga pembelajaran berlangsung dengan kondusif. Hal tersebut sejalan dengan hasil penelitian Dafit yang mengemukakan bahwa keterampilan multiliterasi tersebut tidak dapat muncul jika tidak ada kerjasama antara siswa dengan guru, guru dengan siswa, serta siswa dengan siswa. Artinya dalam proses pembelajaran multiliterasi siswa harus dilibatkan secara langsung dalam proses pembelajaran. (Dafit, 2017a). Dengan demikian, kolaborasi pembelajaran dalam menerapkan model pembelajaran multiliterasi informasi merupakan bagian vital dalam mewujudkan proses pembelajaran yang berkualitas.

Penerapan model pembelajaran multiliterasi informasi di kelas III SD Negeri Mekarjaya III pada mata pelajaran IPS telah meningkatkan pemahaman konsep. Sebagaimana dijelaskan oleh Abidin bahwa salah satu tujuan model multiliterasi adalah "...Pemahaman yang mendalam terhadap berbagai konsep..."(Abidin, 2015). Hal tersebut dilaksanakan berdasarkan tahap model multiliterasi informasi sehingga mampu memperbaiki proses pembelajaran dan memberikan hasil yang baik sebagaimana dijelaskan dalam penelitian Saputra bahwa karakter multiliterasi yang menuntut peserta didik untuk selalu bekerja sama dan berkolaborasi dalam tim untuk memecahkan permasalahan. Peserta didik berkemampuan organisasi rendah akan sulit bekerja sama dalam tim sehingga tujuan pembelajaran akan sulit tercapai juga, begitupun sebaliknya (Saputra, 2018). Dengan demikian, tahap model multiliterasi membuat aktivitas belajar siswa meningkat lebih berpusat pada siswa dan lebih bermakna sehingga siswa memperoleh pemahaman yang baik melalui proses pembelajaran IPS yang dilaksanakan dengan baik dengan menggunakan model multiliterasi informasi. Pembelajaran IPS yang ditempuh oleh siswa akan membina potensi yang dimilikinya sehingga mampu mencapai tujuan yang 
diharapkan selama ini. Sebagaimana dijelaskan oleh Mutakin mengenai tujuan IPS di sekolah yaitu "...Mengetahui dan memahami konsep dasar...".(Adriana \& Setiawan, 2015). Maka melalui pembelajaran IPS siswa akan memperoleh pengetahuan dan pemahaman mengenai kegiatan dasar manusia dan masyarakat meliputi berbagai konsep, maka proses pembelajaran IPS harus dilaksanakan dengan sebaik mungkin sehingga mampu meningkatkan pemahaman konsep siswa. Seperti yang dijelaskan oleh Adriana dan Setiawan bahwa Pemahaman konsep adalah kemampuan mengungkapkan makna atau konsep yang meliputi kemampuan membedakan, menjelaskan, menguraikan lebih lanjut, dan mengubah konsep (Susanto, 2013). Bentuk dari pemahaman konsep berupa pemahaman terjemahan, pemahaman penafsiran, dan pemahaman ekstrapolasi.

Kemampuan tersebut diperoleh siswa ketika telah berhasil menangkap makna atau arti suatu konsep tertentu yang tercermin dari kemampuannya dalam menafsirkan, memberi contoh, mengklasifikasikan, merangkum, membandingkan, menyimpulkan dan menjelaskan. Penerapan model tersebut berdasarkan tahap-tahap prosedural pelaksanaan model multiliterasi informasi menurut Abidin diantaranya: menetapkan masalah, membuat pertanyaan pemandu, menemukan sumber informasi, mencatat informasi, menyeleksi informasi, mengolah informasi, menyimpulkan informasi, memproduksi karya (Abidin, 2015). Melalui tahap tersebut mampu memperbaiki proses pembelajaran karena menggunakan model, dan akan melibatkan sumber belajar yang beragam, serta aktivitas siswa akan meningkat karena pembelajaran lebih berpusat pada siswa, proses pembelajaran demikian dapat meningkatkan pemahaman siswa. Sejalan dengan hal tersebut Ginanjar dan Widayanti mengemukakan bahwa karakteristik model pembelajaran multiliterasi di SD/MI adalah model pembelajaran yang menghubungkan pembelajaran ke dalam kehidupan sehari-hari, dimana siswa ikut terlibat dalam inkuirinya, memberikan peluang untuk mengeluarkan kreativitas, serta melibatkan berbagai ragam belajar dan strategi sebagai sarana pembelajaran. Ginanjar \& Widayanti, 2018). Dengan demikian terbukti hipotesis tindakan penelitian, proses pembelajaran dengan menerapkan model pembelajaran multiliterasi informasi dapat meningkatkan kemampuan pemahaman konsep jual beli pada mata pelajaran IPS di kelas III SD Negeri Mekarjaya III Kecamatan Kertajati Kabupaten Majalengka. 


\section{KESIMPULAN}

Berdasarkan pembahasan yang telah dipaparkan, diperoleh kesimpulan bahwa proses pembelajaran dengan menerapkan model pembelajaran multiliterasi informasi mata pelajaran IPS di kelas III SD Negeri Mekarjaya III Kecamatan Kertajati Kabupaten Majalengka telah berhasil meningkatkan pemahaman konsep jual beli. Pembelajaran multiliterasi informasi melibatkan delapan tahapan yaitu menetapkan masalah, membuat pertanyaan pemandu, menemukan sumber informasi, mencatat informasi, menyeleksi informasi, mengolah informasi, menyimpulkan informasi, dan memproduksi karya. Peran teknologi salah satunya laptop sebagai sumber informasi yang dapat digunakan oleh siswa dalam mencari informasi terkait materi pembelajaran. Proses pembelajaran serta model multiliterasi informasi dapat meningkatkan juga keterampilan menguasai media dan teknologi sebagai sarana sumber informasi yang bisa dimanfaatkan oleh guru maupun peserta didik. 


\section{DAFTAR PUSTAKA}

Abidin, Y. (2015). Pembelajaran Multiliterasi Sebuah Jawaban Atas Tantangan Pendidikan Abad Ke-21 dalam Konteks Keindonesiaan. Bandung: PT Refika Aditama.

Adriana dan Setiawan. (2015). Pengaruh Model Pembelajaran Talking Chips Terhadap Pemahaman Konsep Siswa. 15, 46-56.

Dafit, F. (2017a). Implementasi Model Multiliterasi Pada Proses Pembelajaran Membaca Pemahaman Siswa Kelas IV Sekolah Dasar. 1(2), 7.

Dafit, F. (2017b). Pengaruh Model Pembelajaran Multiliterasi Terhadap Kemampuan Membaca Siswa Sekolah Dasar. Jurnal Inovasi Pendidikan Dan Pembelajaran Sekolah Dasar, 1(1). https:/ / doi.org/10.24036/02017117937-0-00

Deuis, Pramida, Riche, \& Deni, Darmawan. (2018). The Effectiveness Application Of Learning Multiliteracy Model In Development Media Literacy Skills Of Students In BK-TIK Program. 17(1), 12.

Ginanjar, A. Y., \& Widayanti, W. (2018). PENERAPAN MODEL PEMBELAJARAN MULTILITERASI UNTUK MENINGKATKAN KEMAMPUAN LITERASI MATEMATIS SISWA DI SD/MI. 10(2), 8.

Hardiyana, A. (2016). Optimalisasi Pemanfaatan Teknologi Informasi Dan Komunikasi Dalam Pembelajaran PAUD. 2(1), 12.

Hawa, S., \& Ramadhan, A. (2013). Meningkatkan Pemahaman Konsep Sifat-Sifat Benda Cair Dengan Menggunakan Metode Demonstrasi Pada Pembelajaran Sains Siswa Kelas IV SD Inpres 2 Sienjo. 5(2), 11.

Mariyana, F. A., Rosady, I. A., \& Latifah, N. (2018). Pemahaman Konsep Melalui Pendekatan Pendidikan Matematika Realistik Indonesia Pada Materi Pengukuran Sudut Di Kelas IV Sekolah Dasar. 10.

Muhammad, M. (2016). Pengaruh Motivasi Dalam Pembelajaran. 4(2), 11.

Mulyasa, E. (2009). Praktik Penelitian Tindakan Kelas. Bandung: Remaja Rosdakarya.

Puspitasari, A. E., \& Kamsiyati, S. (2015). Peningkatan Pemahaman Konsep Pengukuran Melalui Metode Inkuiri Terbimbing. 5.

Rochiati, Wiriaatmadja. (2013). Metode Penelitian Tindakan Kelas. Bandung: Remaja Rosdakarya.

Saputra, L. (2018). Pengaruh Model Pembelajaran Multiliterasi Dan Kemampuan Berorganisasi Terhadap Kemampuan Analisis Kimia Peserta Didik (Eksperimen Pada Peserta Didik Sma Negeri Di Kecamatan Cilodong Kota Depok). 1(1), 13.

Susanto, A. (2013). Teori Belajar dan Pembelajaran di Dalam Kelas. Jakarta: Kencana Prenada Media Group.

Sutarna, N. (2018). Pengaruh Model Pembelajaran Savi (Somatic Auditory Visual Intellectualy) Terhadap Hasil Belajar Siswa Kelas IV Sekolah 
Penerapan Model Pembelajaran Multiliterasi Informasi Untuk Meningkatkan Pemahaman Konsep Jual Beli

$\begin{array}{lllll}\text { Dasar. Profesi Pendidikan } & 119 .\end{array}$ https:/ / doi.org/10.23917/ppd.v1i2.6068

Yunus Abidin. (2016). Revitalisasi Penilaian Pembelajaran dalam Konteks Pendidikan Multiliterasi Abad Ke-21. Bandung: PT Refika Aditama. 